\title{
ヒトの睡眠中のBruxismに関する臨床的研究，
}

第46 報新しいポータブル記録装醅の概要

Studies of Bruxism during. Sleep,

Part 46. A New Portable Recording Device

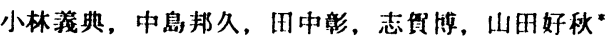

Yoshinori KOBAYASHI, Kunihisa NAKAJIMA, Akira TANAKA, Iliroshi SHIGA, and Yoshiaki YAMADA

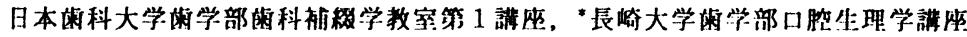

The Nippon Dental University. School of Dentistry at Tokyo, Department of Partial and Complete Denture

* Nagasaki University, School of Dentistry, Department of Oral Physiology

1. 緒言

Bruxismの発生メカニスムについては、未だ 明示されていないのが现状である。

藷者らは、以前よりbruxis in の発生メカニズ

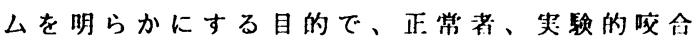

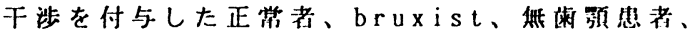
頭蓋下预機能寒㭧者について、然線テレメ一 ターシステムを用いて夜閌睡眠中の生体拀象を 終夜連䌇同㭙記録するとともに、精神内分必反

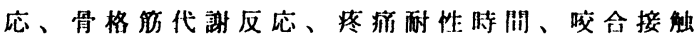

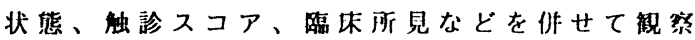
し、経日的な分析を進めている。

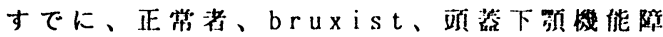
害患者におけるbruxismの㥞相、bruxistにおけ る治癜効果を明らかにするとともに、中心にお

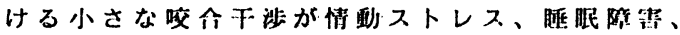

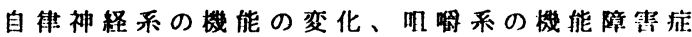
状の発現を伴い、bruxismを持続的に增大させ ることなどを報告いー3いしてきた。

一方、これらの㼋究に用いた船線テレメータ システムは、多くの生体現象を記録、分析でき るが、記録、特に受信装監が大がかりになるた め、記録時に被験者を夹験空もしくはそれに相 当する部屋に就要させなけれはならないために、 一部の被䮖者では、住宅事情により、白宅で記 録することが四難な場命が少なくない。

そこで、このような開题に刘応すべく、萿者

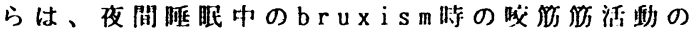
記録が簡便なポータブル記録装琵の開発を試み たので、その概要と茯干の記録結果について㹁
告する。

2. 研笕力法

\section{1 被験者}

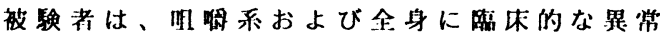
が認められず、また自喾的、他觉的にbruxism

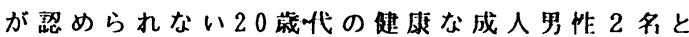

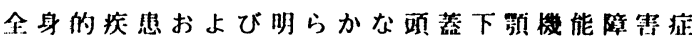
状が認められず、白觉的、他觉的にbruxismが 認められる 20 荿代の成人男性 2 名、寸なわち bruxistを選択した。ここでいう、内觉的とは、 起林時に预のこわばり、疫学感、あるいはbruxismをしていることを認識している状隹、また 他觉的とは、贩らかな彞牙の咬耗面が認めら机、 そのほかに舌や粘膜の栩の压痕が熟められ、さ らに半作以内に他人または身近な家族の考から 「柬きしりをしていた」と2 度以上言われたこ とがある状態である。

\section{2 ポータブル記録装算の概要}

ポータブル記録装固の基本棈成は、イヒデン 妵業社製のコンピュータG-52BS、施電因用アン プ、企波整流器、A/Dコンバータからなる（因 1,2 )。

G-52BSは、BASICインタープリタ内蔵の8052AH のCPU、32 kbyteのRAM、RS232Cインターフェイ ス、タイマで满成し、㭁他因用アンプは、バッ ファアンプ内荿の裴而电椣”と250倍のアンフ

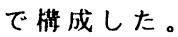

このアンプの出力は、モニタ一端子゙より出力 


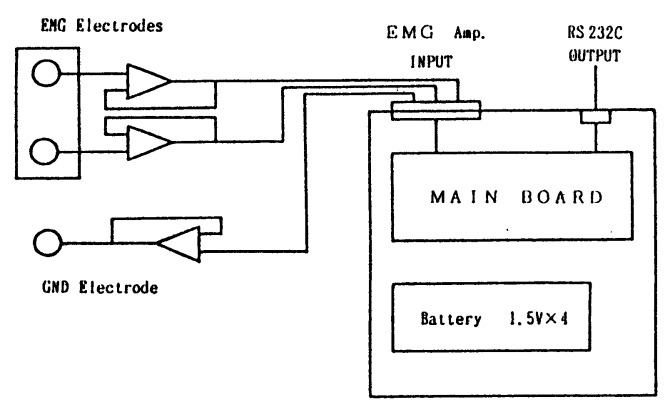

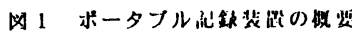

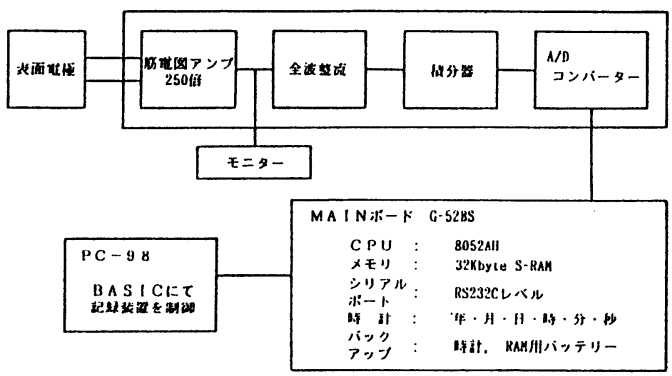

図2 プロックタイアクラム

される。

表面電樰からの施電因信号は、250倍のアン プを通過後、全波整流され、洔定数 0.1 秒の積 分回路を通通中さらに 20 倍增幅された後、 $8 \mathrm{bi} \mathrm{t}$ A/Dコンバータにてテジタル变换され、メモリ 一に記録される。この時、サンプリング周均は、 1 秒で、メモリ一の容量は、現在 10 時間の余裕 があるが、電池の使用時閒により、晛在のとこ ろ8時間の記録を行っている。メモリ一の增設 と電池の持䌇時間の增加は、可能である。

\section{3 記録およひ分析方法}

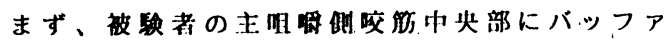

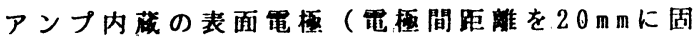
定した直经 $10 \mathrm{~mm}$ の銀性血它骦) を貼付した。次 いで、ポータブル記睩装置をNEC PC-9801のコ ンピュータとRS232Cで接䌇し、PC-9801からの スタートコマンドにより、テータレコーダに記 鋠することと同様に、第電四をサンプリンク周 期 1 秒で 30000 ポイント、約 8 時間記録した。 また、記録は、すへて被筷者の自宅で行つた。
[ Sub. 1 ]

[ Sub. 2 ]

[ Sub. 3 ]

5 min

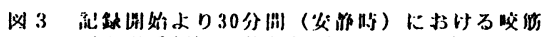

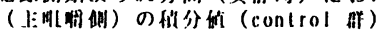

\section{[ Bruxist 1 ]}

[ Bruxist 2]

[ Bruxist 3 ]

$$
5 \mathrm{~min}
$$

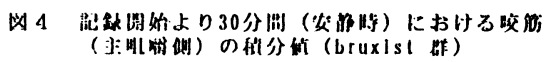

なお、8時間の記録の前に安静時の記録を 30 分 間行った。

分析は、8 時閶の記䤼データから、5分佂に

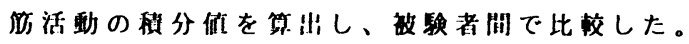

\section{3. 結果とまとめ}

\section{1 安解時 30 分開の㲹鈮}

安静時は、いずれの被験者もゼ口叟位のまま ではなく、かずかな变動がみられた。そこで、 今回の研然では、これらの安静時の值を越える 埸合を觔活動とみなした（因 $3 、 4 ） 。$ 

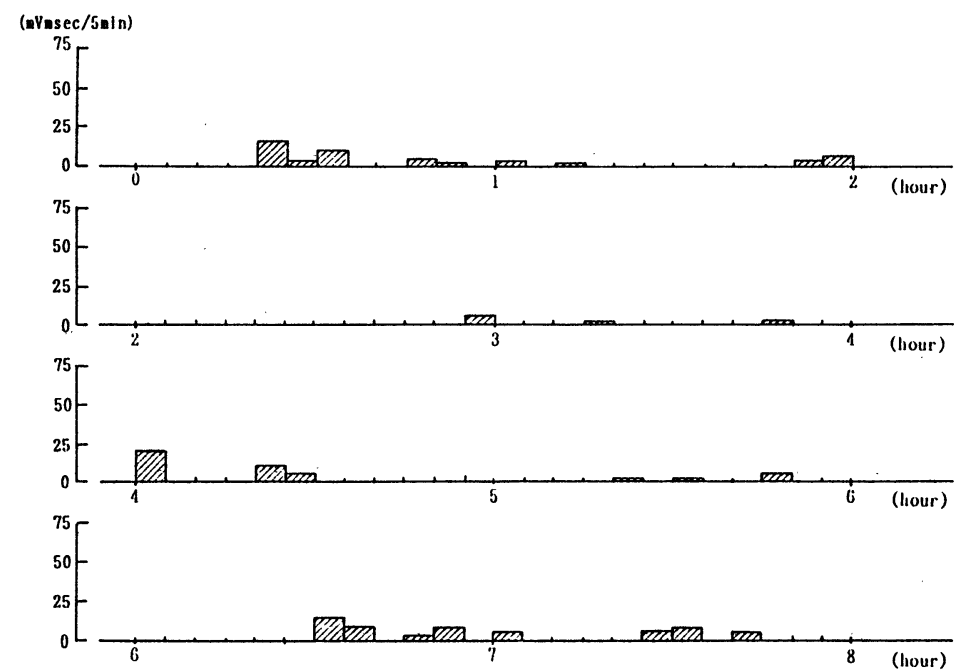

[Sub. 4 ]
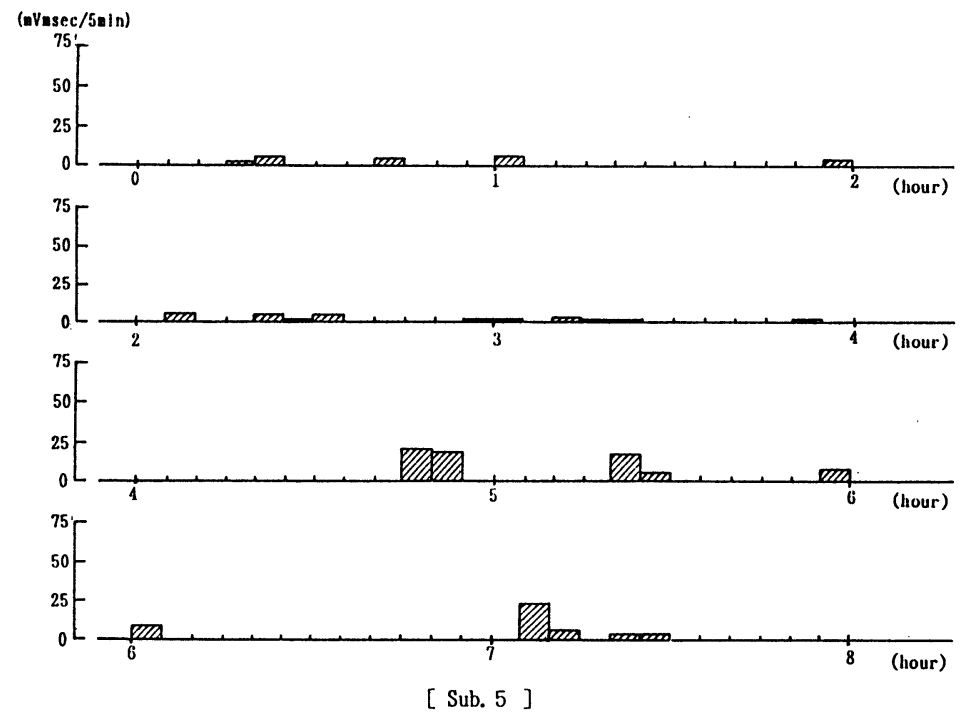

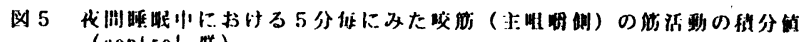
(control at)

3.2 健㩆な成人男性 2 名の夜閌睡眠中にお ける 8 時開の䓰錄

両被験者ともに、終夜にわたり、断続的に筇 活動が認められたが、その频度と鼠が少なかっ た（因 5 ）。

$3.3 \mathrm{Bruxist} 2$ 名の夜間睡眠中における8時 問の記録

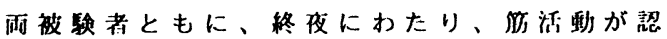
められ、その频度と量が证营被験考に比べて著
明に多かった（因6）。

これらの被雅者は、いずれも十分睡硘がとれ たことを報告した。

3.4 本研究の結果から、新しく開発したポ

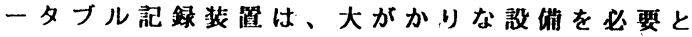
せずに、咬筇施活動（量）を終夜連䌇記録でき ることが確諗できた。したがって、本装触によ り、長拇にわたるbruxismを速䌇記録できるこ とが示唆された。 

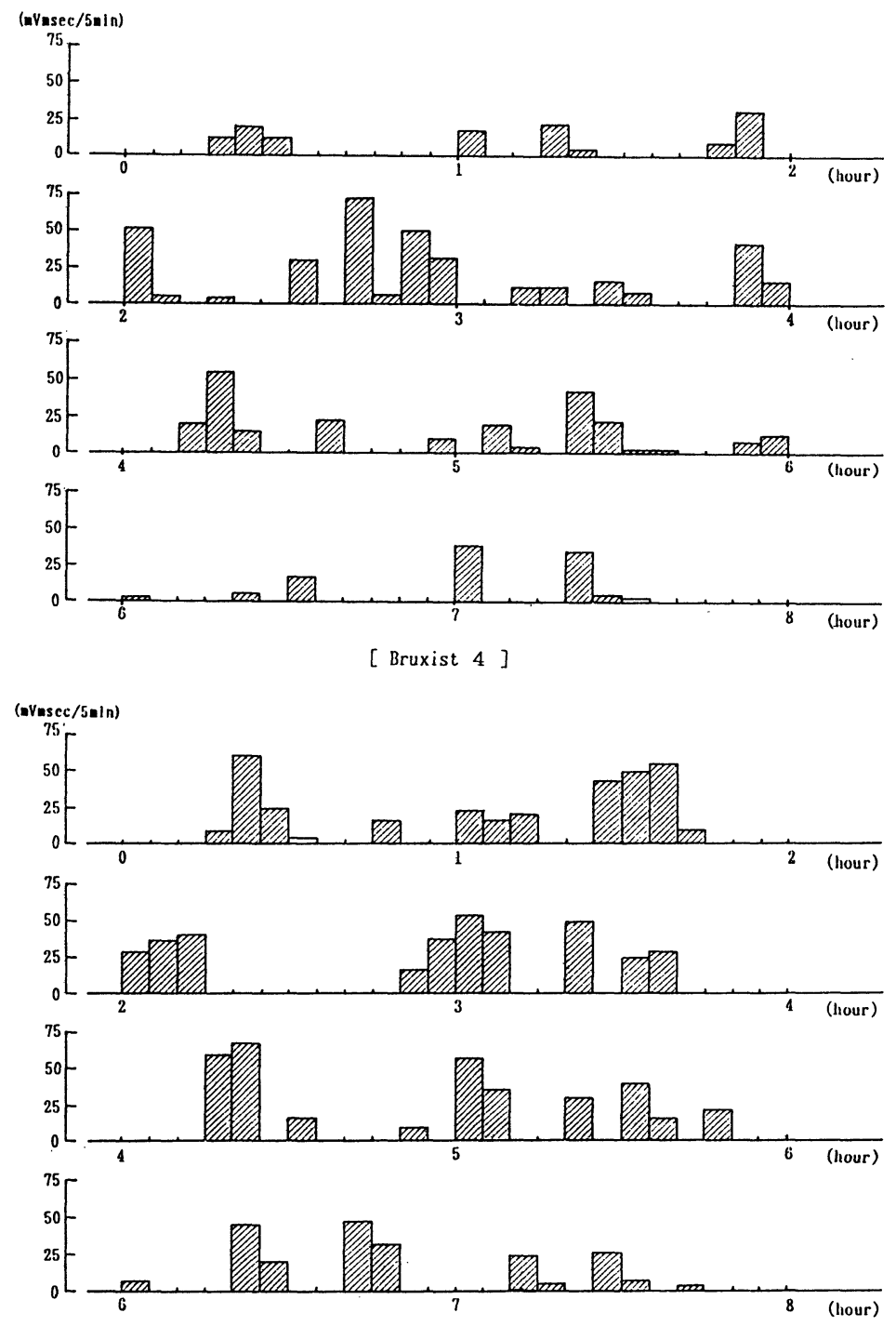

[ Bruxist 5]

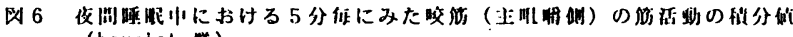
(bruxist If:)

4. 文献

1）小林義典：硕関節症の病因における咬合の

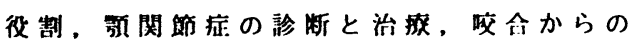

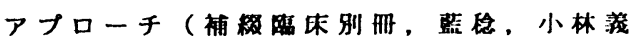

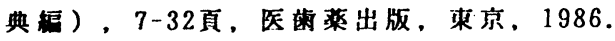

2 )小林義典：いわゆる歌関節应の発症におけ

るbruxismの役割，米科ジャーナル，29: 37 $\sim 52,1989$.

3 )小林義典：ブラキシスム(bruxis m)，弱口

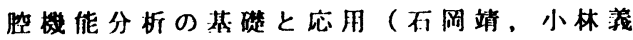
典，辰谷川成男，河野正司，林曹彦綟），第 1 版, $218 \sim 229$ 面, テンタルタイヤモンド 社, 東京, 1991 .

4) Fu.ji isawa, M., Uchida, K., Yamada, Y., and Ishibashi, K.: Surface electromyographic electrode pair with built-in buffer-amplifiers, J Prosthet Dent, $63(3): 350-352,1990$. 